\title{
c.mom \\ Changes in Lithium Levels in Bees and Their Products Following Anti-Varroa Treatment
}

\author{
Éva Kolics ${ }^{1,2}$, Zsófi Sajtos ${ }^{3,4}{ }^{\circledR}$, Kinga Mátyás ${ }^{1}$, Kinga Szepesi ${ }^{1}$, Izabella Solti ${ }^{1}$, Gyöngyi Németh ${ }^{1} \mathbb{1}$, \\ János Taller ${ }^{1}$, Edina Baranyai ${ }^{4}$, András Specziár ${ }^{5}$ and Balázs Kolics ${ }^{1,2, *(D)}$ \\ 1 Festetics Bioinnovation Group, Institute of Genetics and Biotechnology, Georgikon Campus, \\ Hungarian University of Agriculture and Life Sciences, H-8360 Keszthely, Hungary; \\ kolicseva@gmail.com (É.K.); petrovicsnemkk@gmail.com (K.M.); szepesikinga66@gmail.com (K.S.); \\ izabella.solti@gmail.com (I.S.); drnemethgyongyi@gmail.com (G.N.); taller.janos@uni-mate.hu (J.T.) \\ 2 Kolics Apiaries, H-8710 Balatonszentgyörgy, Hungary \\ 3 Doctoral School of Chemistry, University of Debrecen, H-4032 Debrecen, Hungary; \\ sajtos.zsofi@science.unideb.hu \\ 4 Atomic Spectrometry Partner Laboratory, Department of Inorganic and Analytical Chemistry, \\ Faculty of Science and Technology, University of Debrecen, H-4032 Debrecen, Hungary; \\ baranyai.edina@science.unideb.hu \\ 5 Balaton Limnological Research Institute, ELKH, H-8237 Tihany, Hungary; specziar.andras@blki.hu \\ * Correspondence: bkolics@gmail.com; Tel.: +36-302629236
}

check for

updates

Citation: Kolics, É.; Sajtos, Z.; Mátyás, K.; Szepesi, K.; Solti, I.; Németh, G.; Taller, J.; Baranyai, E.; Specziár, A.; Kolics, B. Changes in Lithium Levels in Bees and Their Products Following Anti-Varroa Treatment. Insects 2021, 12, 579. https: / / doi.org/10.3390/ insects12070579

Academic Editor: Yanping(Judy) Chen

Received: 19 May 2021

Accepted: 21 June 2021

Published: 25 June 2021

Publisher's Note: MDPI stays neutral with regard to jurisdictional claims in published maps and institutional affiliations.

Copyright: (c) 2021 by the authors. Licensee MDPI, Basel, Switzerland. This article is an open access article distributed under the terms and conditions of the Creative Commons Attribution (CC BY) license (https:/ / creativecommons.org/licenses/by/ $4.0 /)$.
Simple Summary: Varroosis caused by the ectoparasitic mite Varroa destructor has been the biggest threat to managed bee colonies over recent decades. Chemicals available to treat the disease imply problems of resistance, inconsistent efficacy, and residues in bee products. Recently, alongside novel compounds to defeat the pest, lithium chloride has been found to be effective. In this study, we found that lithium treatments leave beeswax residue-free. The possibility of decontamination in adult bees, bee bread, and uncapped honey was revealed. On the other hand, ripe honey was found to be affected by lithium administered via feeding. Case studies are necessary to uncover the level of exposition in harvested honey to estimate its potential risk once it becomes a registered veterinary medicine.

\begin{abstract}
The biggest threat to beekeeping is varroosis caused by the mite Varroa destructor. Chemicals available to treat this fatal disease may present problems of resistance or inconsistent efficacy. Recently, lithium chloride has appeared as a potential alternative. To date, the amount of residue lithium treatments may leave in honeybee products is poorly understood. Honeybees were fed with $25 \mathrm{mM}$ lithiated sugar syrup, which was used in earlier studies. The accumulation and elimination of the lithium were monitored in bees and their products for 22 days. Lithium concentration increased in the entire body of the bees to day 4 post-treatment and then recovered rapidly to the control level. Lithium exposure was found to affect uncapped honey in the short term ( $<16$ days), but ripe (capped) honey measured at the end of the trial remained affected. On the other hand, lithium treatment left beeswax lithium-free. Based on these data, we propose that comprehensive research on harvested honey is needed to decide on the veterinary use of lithium.
\end{abstract}

Keywords: lithium chloride; beeswax; honey; chemical residues; Apis mellifera; Varroa destructor

\section{Introduction}

Hive products are associated with nutritional benefits and are value-added products of the human food chain. However, honey, beeswax, and bee bread may be exposed to pesticides as a consequence of anti-Varroa treatment.

The overwhelming majority of pollination carried out by honeybees (Apis mellifera) is performed by managed bee colonies [1]. The biggest threat to the honeybee worldwide is varroosis, which involves virus diseases transmitted by the ectoparasite $V$. destructor originally parasitizing a closely related species (A. cerana). If left untreated, mites can 
kill an entire colony within one or two years [2,3], but, in areas of a high density of honeybee colonies, it might occur within an apicultural season. Controls currently in practice based on synthetics can be adequate but are restricted to a few chemicals such as amitraz, coumaphos, flumethrin, and fluvalinate, the formulations of which, however, are demonstrated to lead to the risk of development of resistance [4,5]. As a result, they offer a limited possibility of mite eradication in the foreseeable future. With the exception of oxalic acid, one of the most widely used varroacides [6,7], alternatively used essential oils or organic acids in some instances may be inconsistent in efficacy [8]. Alongside novel approaches (RNAi) to treating varroosis, lithium salts were found to be effective in eradicating $V$. destructor in vitro [9]. Although publications concerning the effects of lithium on harnessed bee individuals are available, these remain restricted to physiological studies [10-12].

Concerning other invertebrates (e.g., sea urchins, marine polychaete worms), disturbances in embryonal development were raised in relation to lithium compounds [13]. Interestingly, however, beneficial effects of lithium on longevity were detected in adult individuals of Drosophila [14]. For both honeybee adults and brood, adverse effects on the longevity of lithiated sugar syrup administration is reported but restricted mainly to in vitro trials $[9,15]$. Furthermore, it is of note that a freely moving bee might react differently to aversive compounds. Being an obligatory social organism, a honeybee colony could actively reject aversive substances [12]. Moreover, feeding sugar syrup infused with varroacide is not typically the way of administering an anti-Varroa treatment in apicultural practice [16].

Lithium chloride (PubChem CID: 433294) may provide an effective, commercially available, and relatively cheap alternative, and therefore, it may be increasingly applied as an unregulated veterinary medicine [16-19]. Despite its potential to treat varroosis in the short term, only a few studies are dealing with the consequences of lithium treatments on honey and other bee products $[15,20]$. However, with honey and beeswax being the most remarkable hive products worldwide, human exposure to lithium when it is used needs to be extensively studied in the apiculture-related food chain to evaluate its impacts before it ever becomes a registered veterinary medicine.

We aimed to understand the consequences of anti-Varroa treatment using lithium chloride feeding, monitoring the changes of the lithium level in the bees and their most important products.

\section{Materials and Methods}

\subsection{Colony Setup and Samplings of Biological Materials and Apicultural Products}

The experiment was started in early October 2018 in Hungary (Keszthely, 46 $45^{\prime} 55.6^{\prime \prime}$ $\mathrm{N}, 17^{\circ} 14^{\prime} 52.6^{\prime \prime} \mathrm{E}$ ), excluding outer nectar flow. Carniolan (A. m. carnica) colony splits were populated into four hives (local type). On the same day (day 6), colonies were transferred away from their flight range into a dark room and kept for five days. Apart from one frame originating from the donor colonies, each hive was equipped with wax foundations (day 3) only. After making sure the colonies were queenright, they were placed outdoors in the evening of day 1 . Hives were set at least $3 \mathrm{~m}$ away from each other, with geographical landmarks to prevent drifting.

Sampling was initiated on day zero. Before treatment, bees and their products were sampled to measure control lithium concentrations in the four hives. Then, the frame originating from the donor colonies containing the honey and bee bread store from pretreatment was discarded from each hive. The colonies were subsequently fed with one liter of 1:1 sucrose syrup containing $25 \mathrm{mM}$ lithium chloride (126.5 $\left.\mathrm{mg} \mathrm{kg}^{-1} \mathrm{Li}+\right)$ [9].

Sampling was carried out in a standardized manner to prevent cross-contamination of the hive products as follows. First, bottom boards were cleaned to collect hive debris. Adult bees ( 25 workers, mixed of age, from each hive in each occasion) were collected from the bee space of the hives to make a pooled sample. To be able to sample beeswax secreted under lithium exposure from the hive, the colony was forced to build brace combs (about 
$10 \times 10 \mathrm{~cm}$ in size). Cells from which the bee bread was collected ( $\mathrm{g}$ from each hive) were marked to prevent their re-sampling (except the pre-treatment control originating from the donor colony). Taken from all combs, $30 \mathrm{~mL}$ honey was collected from each hive on each sampling occasion. Samplings were carried out on day 0 (pre-treatment control), and days $1,4,8,16$, and 22 (post-treatment) for hive debris $(n=24)$, bees $(n=24)$ divided later into three body parts (head, thorax and abdomen, and legs), brace combs $(n=19)$, bee bread $(n=24)$, and uncapped (unripe) honey $(n=24)$.

The experiment was terminated on day 28. Queens were killed to examine their whole body $(n=4)$. Mature, capped honey was sampled $(n=4)$. Beeswax was rendered from the combs; during this process, slumgum was collected $(n=4)$. Furthermore, sediments $(n=4)$ of the wax cakes and the melting waters $(n=4)$ in which the wax $(n=4)$ was processed were collected. Altogether, 139 different samples were collected. An overview of the whole sampling process is visualized in Figure 1.

\subsection{Sample Preparation}

Samples were stored at $-5^{\circ} \mathrm{C}$ in plastic tubes before the sample pre-treatment process. Bees' heads were measured separately since pharyngeal glands produce and excrete royal jelly, presenting the food for honeybee larvae. The lithium content of the legs was measured separately.

Bees were separated into the three main parts according to the details above: approx. $75 \mathrm{mg}$ for the head, and the same amount for the legs, and approx. $500 \mathrm{mg}$ for the thorax \& abdomen in each sampling. The body parts, as well as the exact known weight of honey and beeswax ( $0.5 \mathrm{~g}$ of each), bee bread, and hive debris ( $0.1 \mathrm{~g}$ of each), were measured on an analytical balance (ES 225SM-DR, Precisa, Dietikon, ZH, USA) into $50 \mathrm{~mL}$ glass beakers. Samples were dried at $50{ }^{\circ} \mathrm{C}$ to constant weight in an electric drying cabinet.

Dried samples were wet digested in the same vessels by the mixture of $4.0 \mathrm{~mL} 65 \%$ $(\mathrm{m} / \mathrm{m}) \mathrm{HNO}_{3}$ (reagent grade, Scharlau, Germany) and $1.0 \mathrm{~mL} \mathrm{30 \%} \mathrm{(m/m)} \mathrm{H}_{2} \mathrm{O}_{2}$ (reagent grade, Merck, Kenilworth, NJ, USA) to evade the cross-contamination from changing glassware. Digested samples were transferred without loss into volume calibrated plastic centrifuge tubes and diluted up to the volume of $10.00 \mathrm{~mL}$ with ultrapure water (Synergy UV, Sigma-Aldrich, St. Louis, MO, USA). Solutions were kept at room temperature before further elemental analysis. Each piece of glassware used was decontaminated by immersion in a 1:5 $\mathrm{HNO}_{3}: \mathrm{H}_{2} \mathrm{O}$ solution for $24 \mathrm{~h}$ and rinsed with deionized water before use.

\subsection{Analytical Measurements}

The quantitative analysis of the lithium content in the different samples was carried out by microwave plasma atomic emission spectrometry (MP-AES 4200, Agilent Technologies, Santa Clara, CA, USA). The plasma gas was continuously supplied during measurement by a nitrogen generator (4107, Agilent Technologies). The MP-AES instrument operates with a vertical torch alignment together with an axial observation position. As well as sample solutions, standards were introduced by autosampler (SPS, Agilent Technologies) with $30 \mathrm{~s}$ of rinsing between each with $0.1 \mathrm{M} \mathrm{HNO}_{3}$ prepared in ultrapure water. The MPAES operating conditions and measurement parameters are indicated in Table 1. Lithium standard stock solution of $1000 \mathrm{mg} \mathrm{L}^{-1}$ (Scharlau, Germany) was used to prepare the 5 -point calibration series. The limit of detection (LOD) was defined as $0.3246 \mu \mathrm{g} \mathrm{kg}^{-1}$ at the applied wavelength of $610.365 \mathrm{~nm}$ (the measurement parameters are summarized in Table 1). 


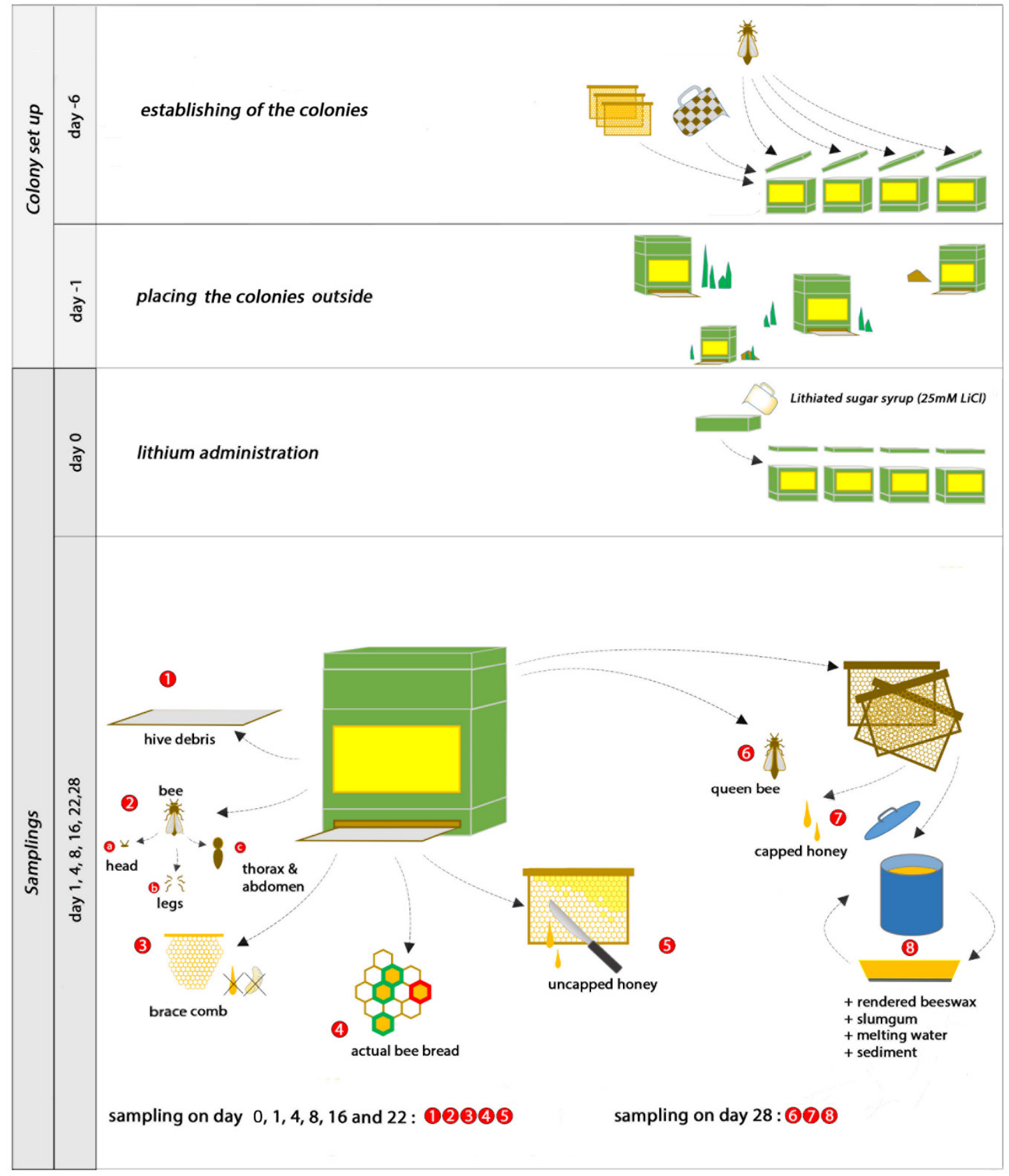

Figure 1. Experimental design and samplings.

Table 1. Analytical measurement parameters.

\begin{tabular}{cc}
\hline Replicates & $\mathbf{3}$ \\
Pump Speed & $\mathbf{1 5} \mathbf{~ r p m}$ \\
\hline Uptake time & $15 \mathrm{~s}$ \\
Rinse time & $30 \mathrm{~s}$ \\
Stabilization time & $15 \mathrm{~s}$ \\
Read time & $3 \mathrm{~s}$ \\
Nebulizer pressure & $240 \mathrm{kPa}$ \\
Wavelength & $610.365 \mathrm{~nm}$ \\
\hline
\end{tabular}


The following formula calculated the LOD: LOD $=(3 \times s) / S$ where $s$ is the standard deviation of 15 blank samples, and $S$ is the specificity (slope of the calibration curve). The results of the elemental analysis were given on a dry mass basis.

\subsection{Statistical Analysis}

To analyze the effect of $\mathrm{LiCl}$ treatment on the Li concentration of bees (head, thorax and abdomen, and leg were analyzed separately), honey, bee bread, beeswax and hive debris (response variables), we used linear mixed models (LMMs) in Statistica 8.0 (http: / / www.statsoft.hu) (accessed on 19 May 2021). Prior to analysis, Li concentration data were $\log 10$ transformed to improve normality. The LMMs included sampling time as a fixed factor representing pre-treatment (control, at day 0) and post-treatment measurements (days 1, 4, 8, 16, and 22). In order to account for repeated measures, the hive was included as a random factor. Differences among means were identified using Tukey HSD post hoc tests when the model fixed effect was significant.

\section{Results and Discussion}

\subsection{Lithium Level Returns to Normal Values in Adult Bees}

Feeding lithium syrup at a concentration $(25 \mathrm{mM})$ applied in earlier studies $[9,15,20]$ resulted in an average lithium peak of $130.13 \mathrm{mg} \mathrm{kg}^{-1}$ (average of the hives) in bees' bodies (thorax and abdomen), with an absolute maximum value of $167.71 \mathrm{mg} \mathrm{kg}^{-1}$ in hive 1 , on day 4 . Lithium concentration decreased in all body parts of the bees from day 4 post-treatment (Table 2, Figure 2). This pattern may be consistent with the findings of Prešern and colleagues, who revealed that in bee larvae, lithium level started to drop on day 3 post-treatment [15]. By day 22 post-treatment, lithium level showed full recovery to the pre-treatment control level $\left(0.15 \mathrm{mg} \mathrm{kg}^{-1}\right.$ on average; Figure 2$)$. Data from the present study indicate that adult bees seem to be able to excrete lithium at the colony level.

Table 2. Effect of lithium in bees and bee products in factor of time. Analysis of log-transformed Li concentration data using linear mixed models revealed a significant effect of time relative to the $\mathrm{LiCl}$ treatment (control: pre-treatment (day 0 ); treated: 1, 4, 8, 16, and 22 days post-treatment) of honeybee colonies on lithium concentration of the bees, the honey, and the bee bread, but not that of the wax and the hive debris. Results of Tukey HSD post hoc tests are shown in Figure 2.

\begin{tabular}{|c|c|c|c|c|c|c|c|c|c|}
\hline \multicolumn{4}{|c|}{ Main Effects } & \multicolumn{6}{|c|}{ Overall Model } \\
\hline & Factor & Effect type & $\begin{array}{r}\text { d.f. } \\
\text { (Effect, Error) }\end{array}$ & $\mathbf{F}$ & $p$ & $\mathbf{R}_{\text {adj. }}^{2}$ & $\begin{array}{r}\text { d.f. } \\
\text { (Model, } \\
\text { Residual) }\end{array}$ & $\mathbf{F}$ & $p$ \\
\hline Bee head & $\begin{array}{l}\text { day } \\
\text { hive }\end{array}$ & $\begin{array}{l}\text { fixed } \\
\text { random }\end{array}$ & $\begin{array}{l}5,15 \\
3,15\end{array}$ & $\begin{array}{r}154.4 \\
0.8\end{array}$ & $\begin{array}{r}<0.001 \\
0.529\end{array}$ & 0.971 & 8,15 & 96.8 & $<0.001$ \\
\hline $\begin{array}{l}\text { Bee thorax and } \\
\text { abdomen }\end{array}$ & $\begin{array}{l}\text { day } \\
\text { hive }\end{array}$ & $\begin{array}{l}\text { fixed } \\
\text { random }\end{array}$ & $\begin{array}{l}5,15 \\
3,15\end{array}$ & $\begin{array}{r}395.1 \\
2.5 \\
\end{array}$ & $\begin{array}{r}<0.001 \\
0.102 \\
\end{array}$ & 0.988 & 8,15 & 247.9 & $<0.001$ \\
\hline Bee leg & $\begin{array}{l}\text { day } \\
\text { hive }\end{array}$ & $\begin{array}{l}\text { fixed } \\
\text { random }\end{array}$ & $\begin{array}{l}5,15 \\
3,15\end{array}$ & $\begin{array}{r}156.2 \\
0.7 \\
\end{array}$ & $\begin{array}{r}<0.001 \\
0.592 \\
\end{array}$ & 0.971 & 8,15 & 97.9 & $<0.001$ \\
\hline Honey & $\begin{array}{l}\text { day } \\
\text { hive }\end{array}$ & $\begin{array}{l}\text { fixed } \\
\text { random }\end{array}$ & $\begin{array}{l}5,15 \\
3,15\end{array}$ & $\begin{array}{r}57.3 \\
1.7 \\
\end{array}$ & $\begin{array}{r}<0.001 \\
0.210 \\
\end{array}$ & 0.925 & 8,15 & 36.5 & $<0.001$ \\
\hline Bee bread & $\begin{array}{l}\text { day } \\
\text { hive }\end{array}$ & $\begin{array}{l}\text { fixed } \\
\text { random }\end{array}$ & $\begin{array}{l}5,15 \\
3,15\end{array}$ & $\begin{array}{l}6.6 \\
0.8 \\
\end{array}$ & $\begin{array}{l}0.002 \\
0.512 \\
\end{array}$ & 0.543 & 8,15 & 4.4 & 0.006 \\
\hline Hive debris & $\begin{array}{l}\text { day } \\
\text { hive }\end{array}$ & $\begin{array}{l}\text { fixed } \\
\text { random }\end{array}$ & $\begin{array}{l}5,15 \\
3,15\end{array}$ & $\begin{array}{l}1.0 \\
1.0\end{array}$ & $\begin{array}{l}0.451 \\
0.418\end{array}$ & 0.000 & 8,15 & 1.0 & 0.474 \\
\hline
\end{tabular}



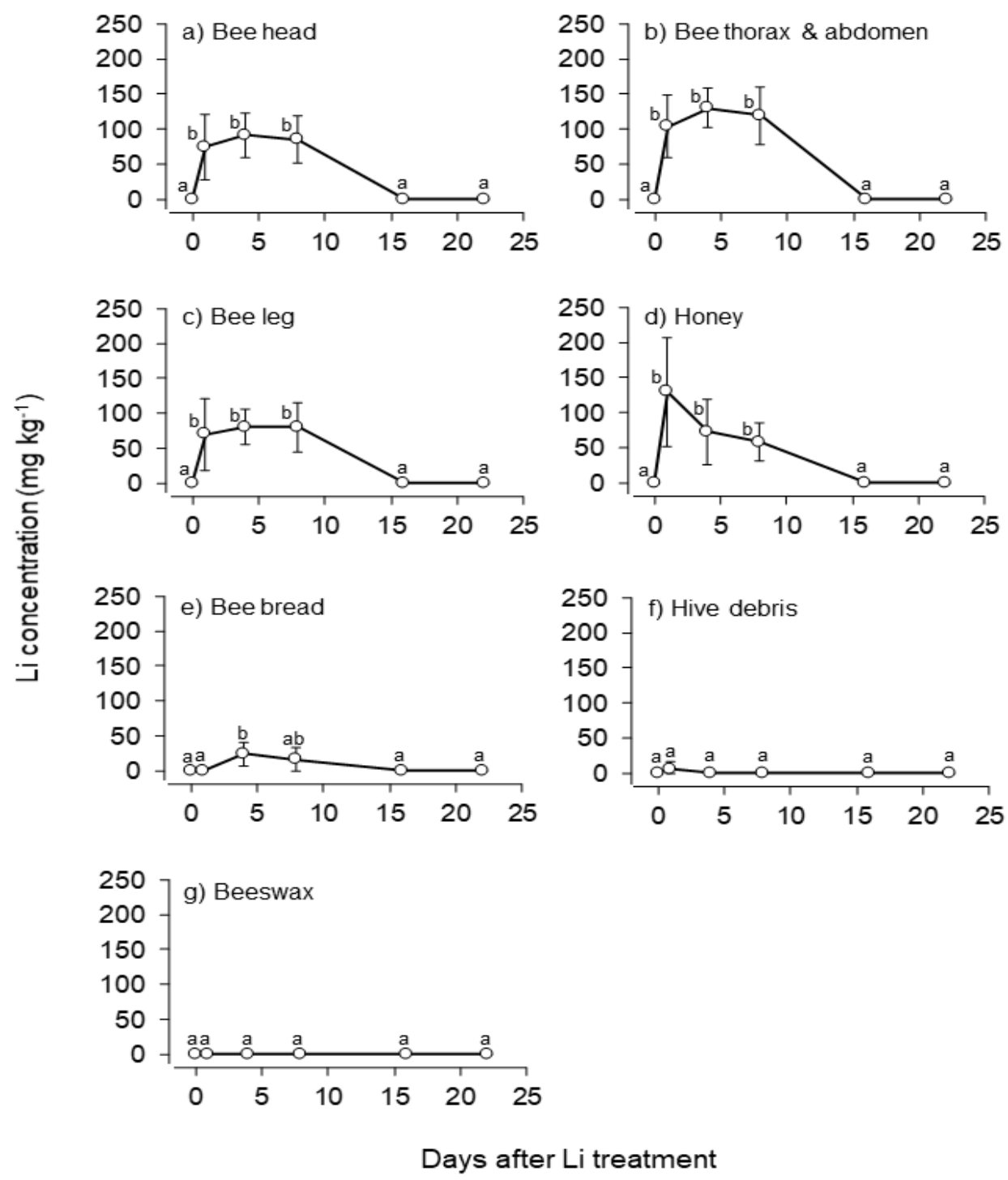

Figure 2. Post-treatment changes in lithium concentration in hive products and bees. Linear mixed model analysis (LMM) revealed a significant increase in Li concentrations (mean \pm SD) in bee head (a), thorax and abdomen (b), and leg (c), as well as in honey (d) between 1 and 8 days after $\mathrm{LiCl}$ treatment, followed by a return of concentrations to the control level after 16 days post-treatment. Only a small increase in Li concentration was revealed in bee bread (e), and only on the 4th day post-treatment, and no increase in Li concentration at all was detected in hive debris (f) or beeswax (g). For LMM statistics, see Table 2. Plotted values not sharing any index letter are statistically different at $p<0.05$ (Tukey HSD post hoc test). Note that the threshold of detecting Li was $0.0003 \mathrm{mg} \mathrm{kg}^{-1}$.

Residues were found in the entire body of bees, reaching the legs as well, the parts of the body in which lithium may have been transferred via the hemolymph. Therefore, all parts of the bees' bodies may be eligible to estimate changes in the lithium level of the colony. We hypothesize that the Li concentration peak measured in the bees and their offspring might help to predict the timeframe of treatment efficacy for future research in this field.

A sampling of the queens was only possible by killing the individuals. Therefore, the queens were measured only at the termination of the trial (day 28), revealing no detectable lithium. No signs of an attempt to refuse the queens by the worker bees, known as supersedure, were observed in the whole period of the experiment. We conclude that lithium has no detrimental effect on the queen, at least in the short term. 
Hive debris usually contains wax particles and may contain bee parts, traces of honey, or pollen in a variable composition. Nonetheless, it revealed no response to $\mathrm{LiCl}$ treatment (Table 2, Figure 2). Despite being readily available without opening the hive, the debris does not appear to be suitable for collecting information about the lithium level in the hive.

\subsection{Bee Bread Is the Least Affected of Beekeeping Products}

Of the bee products in which lithium appeared, the stored, fermented pollen (known as bee bread) was found to be the least exposed to lithium contamination (Table 2).

Bee bread is commercialized for its beneficial nutritional and therapeutic properties. However, collecting it for human food is time-consuming and suffers from limitations [21]. Similar to other samples investigated, lithium peaked on day 4 with a lithium level of $28.11 \mathrm{mg} \mathrm{kg}^{-1}$ (Figure 2). Representing four hives but a single time measurement, a similar value (30.75 $\mathrm{mg} \mathrm{kg}^{-1}$ ) was reported for day 4 post-treatment by Prešern and collegues [15]. Bee bread is the primary protein resource that bees utilize, especially for feeding larvae and adults. High lithium exposure may adversely affect the development of the larvae [15]. Furthermore, increased mortality in the lithium-treated colonies was recorded. Thus, lithium treatment may have an impact on colony reproduction. Nevertheless, reduced lithium levels were measured in 5-day-old larvae three days after the lithium culmination (on day 7 post-treatment). [22].

Our data support the rapid decrease of $\mathrm{LiCl}$ in the bee bread after the peak caused by treatment (Figure 2). Lithium concentration recovery in adult bees and in the diet of larvae enables the brood to be less exposed over time. We propose that the possible adverse effects of lithium might be compensated for or minimized by applying it only in naturally or artificially induced brood-free or brood-poor periods. It should be noted, however, that the veterinary use of $\mathrm{LiCl}$ has not been authorized yet. Further research is needed to accurately determine a low-risk timing or a withholding period in queen rearing.

\subsection{Lithium Treatment Leaves Beeswax Unaffected}

In brace combs, representing the wax secreted directly by the bees, no lithium was detected in any samples $(n=19)$ at any sampling time (Figure 2$)$. No lithium was detected in any lumps of wax $(n=4)$ rendered from the old combs of the hives, either. Moreover, in by-products of the wax rendering process from old combs such as the slumgum, sediment, and the melting water, no lithium content has been confirmed. These facts are of great importance as comb wax is commonly recycled in apicultural practice; recycled comb is used to make beeswax foundations and widely distributed to beekeepers.

Our finding is significant also because other commonly used acaricides such as amitraz [23], coumaphos [24], tau fluvalinate [25], flumethrin [26], and thymol [27] affect the beeswax.

\subsection{Lithium Levels Decrease during Dehydration, but Residues May Remain in the Ripe Honey}

Honey, the most important apicultural product, represents aggregate honey taken from thousands of honey storage sites from capped and uncapped cells.

Uncapped cells initially contain freshly collected unripe nectar, which undergoes the process of dehydration and transposition to cells to be filled into the vicinity of the brood, where they are then capped by the bees. In the present study, uncapped honey served to uncover the kinetics of lithium within the hive, whilst capped honey was separately handled to represent the store to be harvested at the termination of the experiment.

Treatment with lithiated sugar syrup containing $126.5 \mathrm{mg} \mathrm{kg}^{-1} \mathrm{LiCl}(25 \mathrm{mM})$ affected the uncapped honey considerably in the short term (Table 2, Figure 2). The highest lithium content in the honey was measured on day 1 (Figure 2). Despite the dehydration process of the honey carried out by the bees, the concentration of lithium started to decrease from day 4 post-treatment. Lithium concentration in uncapped honey showed full recovery to the control level (below $0.25 \mathrm{mg} \mathrm{kg}^{-1}$ ) by day 22. Based on the obtained data, the possibility of decontamination of uncapped honey has been confirmed. This hive product, being 
the transposed honey stock of the colony, is most affected by lithium. Incoming nectar or sugar syrup is processed and exposed to transposition from being passed from bee to bee several times. It is hypothesized that one possible point of lithium depletion may occur via the bees.

In the capped, ripe honey, a value corresponding to one-fifth of the initial lithium syrup concentration $\left(22.40 \mathrm{mg} \mathrm{kg}^{-1}\right)$ was measured on average at the termination of the experiment (day 28). This amount may be comparable to the natural lithium trace element content measured in honey so far [28]. Honey exerts positive nutritional and health effects if consumed at high doses of 50 to $80 \mathrm{~g}$ per daily intake [29]. Considering it as a proposed intake, capped honey from the present trial would equal 1.12-1.79 $\mathrm{mg}$ lithium. This amount can be achieved from other alimentary products as a daily lithium intake [30-32]. It is of note that hardly any similar modes of administration are used in which the anti-Varroa active ingredient is applied via a large amount of sugar syrup (e.g., feeding), since it will inevitably induce an elevated residue level in the honey store. Although a single treatment is not likely to result in an alarming level in ripe honey, a trickling mode of administration may be preferred once lithium is registered as a veterinary medicine.

\section{Conclusions}

In this study, the progress of contamination and the possibility of subsequent elimination of lithium in the most important bee products and adult bees were investigated in situ after lithiated sugar syrup feeding. Unlike commonly used varroaicides, lithium treatment left beeswax unexposed as a clear positive property of lithium. On the other hand, it was revealed that lithium could contaminate ripe honey. Despite inducing the pollution of the honey by feeding the bees lithiated syrup, lithium levels remained under the level of commercialized honey, which naturally possess higher lithium content (38-110 mg/ $\mathrm{kg}^{-1}$ [28,33]. Currently, no maximum residue levels (MRL) exist for lithium, nor it is recognized as veterinary medicine. More extensive research is needed to determine lithium residues under field conditions in harvested honey and bee bread, as well as to determine a waiting time after the Li treatment. Further experiments are necessary to reveal how application methods like trickling [16] would affect the appearance of residues in honey, especially if performed repeatedly against the devastating pest $V$. destructor.

Author Contributions: Conceptualization, É.K. and B.K.; methodology, B.K. and K.M.; software, A.S.; validation, A.S.; investigation, K.M., É.K., B.K., Z.S., and E.B.; resources, B.K. and E.B.; data curation, A.S.; writing—original draft preparation, É.K., B.K., K.M., K.S., E.B., and Z.S.; writing-review and editing, B.K., É.K., K.M., G.N., I.S., and A.S.; visualization, B.K. and A.S.; funding acquisition, J.T. and B.K. All authors have read and agreed to the published version of the manuscript.

Funding: This research and the APC was supported by the Hungarian Government and the European Union, with the co-funding of the European Regional Development Fund in the frame of Széchenyi 2020 Programme GINOP-2.3.2-15-2016-00054 project.

Institutional Review Board Statement: Not applicable.

Data Availability Statement: Not applicable.

Acknowledgments: We would like to thank Mr Imre Bognár for providing the colonies for the experiment. We would like to highly acknowledge Agilent Technologies (Novo-Lab Ltd., Dallas, TX, USA) for providing an MP-AES 4200 instrument for the elemental analysis. This publication was supported by the GINOP-177 2.3.2-15-2016-00054 project.

Conflicts of Interest: The authors declare no conflict of interest. The funders had no role in the design of the study, in the collection, analyses, or interpretation of data, or the writing of the manuscript. 


\section{References}

1. Genersch, E. American foulbrood in honeybees and its causative agent, Paenibacillus larvae. J. Invertebr. Pathol. 2010, 103, S10-S19. [CrossRef] [PubMed]

2. Spivak, M.; Reuter, G. A Sustainable Approach to Controlling Honey Bee Diseases and Varroa Mites; USDA: Washington, DC, USA, 2005; pp. 1-6.

3. Barlow, V.M.; Fell, R.D. Sampling Methods for Varroa Mites on the Domesticated Honeybee; Virginia Cooperative Extension: Virginia, VA, USA, 2006; pp. 1-3. Available online: http:/ /hdl.handle.net/10919/50392 (accessed on 19 May 2021).

4. Mozes-Koch, R.; Slabezki, Y.; Efrat, H.; Kalev, H.; Kamer, Y.; Yakobson, B.; Dag, A. First detection in Israel of fluvalinate resistance in the varroa mite using bioassay and biochemical methods. Exp. Appl. Acarol. 2000, 24, 35-43. [CrossRef] [PubMed]

5. Spreafico, M.; Bernardinelli, I.; Colombo, M.P. First detection of strains of Varroa destructor resistant to coumaphos. Results of laboratory tests and field trials. Apidologie 2001, 32, 49-55. [CrossRef]

6. Coffey, M.F.; Breen, J. The efficacy and tolerability of Api-Bioxal ${ }^{\circledR}$ as a winter varroacide in a cool temperate climate. J. Apic. Res. 2016, 55, 65-73. [CrossRef]

7. Al Toufailia, H.; Francis, L.W.R. Towards integrated control of varroa: 5) Monitoring Honey bee brood rearing in winter, and the proportion of varroa in small patches of sealed brood cells. J. Apic. Res. 2018, 57, 444-451. [CrossRef]

8. Rosenkranz, P.; Pia, A.; Bettina, Z. Biology and control of varroa destructor. J. Invertebr. Pathol. 2010, 103, S96-S119. [CrossRef] [PubMed]

9. Ziegelmann, B.; Elisabeth, A.; Stefan, H.; Michaela, B.; Stefan, B.; Peter, R. Lithium chloride effectively kills the honey bee parasite varroa destructor by a systemic mode of action. Sci. Rep. 2018, 8, 683. [CrossRef]

10. Hurst, V.; Philip, C.S.; Geraldine, A.W. Toxins induce "Malaise' behaviour in the Honeybee (Apis Mellifera)". J. Comp. Physiol. A 2014, 200, 881-890. [CrossRef] [PubMed]

11. Whitehead, A.T. Electrophysiological response of honey bee labial palp contact chemoreceptors to sugars and electrolytes. Physiol. Entomol. 1978, 3, 241-248. [CrossRef]

12. Ayestaran, A.; Martin, G.; María, G.d.B.S. Toxic but Drank: Gustatory aversive compounds induce post-ingestional malaise in harnessed honeybees. PLoS ONE 2010, 5, e15000. [CrossRef]

13. Léonard, A.; Hantson, P.; Gerber, G. Mutagenicity, carcinogenicity and teratogenicity of lithium compounds. Mutat. Res. Genet. Toxicol. 1995, 339, 131-137. [CrossRef]

14. Castillo-Quan, J.I.; Tain, L.S.; Kinghorn, K.J.; Li, L.; Gronke, S.; Hinze, Y.; Blackwell, K.T.; Bjedov, I.; Partridge, L. A triple drug combination targeting components of the nutrient-sensing network maximizes longevity. Proc. Natl. Acad. Sci. USA 2019, 116, 20817-20819. [CrossRef]

15. Prešern, J.; Kur, U.; Bubnič, J.; Šala, M. Lithium contamination of honeybee products and its accumulation in brood as a consequence of anti-varroa treatment. Food Chem. 2020, 330, 127334. [CrossRef] [PubMed]

16. Kolics, É.; Specziár, A.; Taller, J.; Mátyás, K.; Kolics, B. Lithium chloride outperformed oxalic acid sublimation in a preliminary experiment for varroa mite control in pre-wintering honey bee colonies. Acta Vet. Hung. 2021, 68, 370-373. [CrossRef] [PubMed]

17. Stanimirovic, Z.; Uroš, G.; Marko, R.; Nevenka, A.; Nemanja, J.; Branislav, V.; Jevrosima, S. Looking for the causes of and solutions to the issue of honey bee colony losses. Acta Vet. Beogr. 2019, 69, 1-31. [CrossRef]

18. Ziegelmann, B.; Blumenschein, M.; Rein, C.; Lang, V.; Hannus, S.; Rosenkranz, P. Varroa Treatment of Brood-Free Honey Bee Colonies with Lithium Chloride. In Proceedings of the 46th APIMONDIA-International Apicultural Congress, Montréal, QC, Canada, 8-12 September 2019.

19. Kolics, É.; Kinga, M.; János, T.; András, S.; Balázs, K. Contact effect contribution to the high efficiency of lithium chloride against the mite parasite of the honey bee. Insects 2020, 11, 333. [CrossRef]

20. Kolics, B.; Sajtos, Z.; Matyas, K.; Kolics, É.; Taller, J.; Baranyai, E. Lithium Chloride—Hazard or Possibility? In Proceedings of the 46th APIMONDIA-International Apicultural Congress: Montréal, QC, Canada, 8-12 September 2019.

21. Khalifa, S.A.; Elashal, M.; Kieliszek, M.; Ghazala, N.E.; Farag, M.A.; Saeed, A.; Xiao, J.; Zou, X.; Khatib, A.; Göransson, U.; et al. Recent insights into chemical and pharmacological studies of bee bread. Trends Food Sci. Technol. 2020, 97, 300-316. [CrossRef]

22. Prešern, J. Neurostatistical approach to toxicological testing in honeybees. MethodsX 2020, 7, 101077. [CrossRef]

23. Jiménez, J.J.; José, L.B.; María, J.d.N.; María, T.M. Residues of organic contaminants in beeswax. Eur. J. Lipid Sci. Technol. 2005, 107, 896-902. [CrossRef]

24. Bajuk, B.P.; Katarina, B.; Tomaž, S.; Luka, M.; Metka, P.; Ocepek, M.Š.; Vlasta, J.; Ayhan Filazi, D.Š.; Silvestra, K. Coumaphos residues in honey, bee brood, and beeswax after varroa treatment. Apidologie 2017, 48, 588-598. [CrossRef]

25. Wilmart, O.; Anne, L.; Marie-Louise, S.; Wim, R.; Bruno, U.; Dirk, C.D.G.; Walter, S.; Philippe, D.; Pascal, G.; Bach, K.N. Residues in Beeswax: A health risk for the consumer of honey and beeswax? J. Agric. Food Chem. 2016, 64, 8425-8434. [CrossRef]

26. Bogdanov, S.; Verena, K.; Ueli, B. Determination of acaricide residues in beeswax: Collaborative study. Apiacta 2003, 38, 235-245.

27. Carayon, J.-L.; Téné, N.; Bonnafé, E.; Alayrangues, J.; Hotier, L.; Armengaud, C.; Treilhou, M. Thymol as an alternative to pesticides: Persistence and effects of Apilife Var on the phototactic behavior of the honeybee Apis mellifera. Environ. Sci. Pollut. Res. 2013, 21, 4934-4939. [CrossRef] [PubMed]

28. Hernández, O.M.; Fraga, J.M.G.; Jiménez, A.I.; Jiménez, F.; Arias, J.J. Characterization of honey from the Canary Islands: Determination of the Mineral content by atomic absorption spectrophotometry. Food Chem. 2005, 93, 449-458. [CrossRef] 
29. Bogdanov, S.; Jurendic, T.; Sieber, R.; Gallmann, P. Honey for Nutrition and Health: A Review. J. Am. Coll. Nutr. 2008, 27, 677-689. [CrossRef]

30. Voica, C.; Roba, C.; Iordache, A.M. Lithium levels in food from the romanian market by Inductively Coupled Plasma-Mass Spectrometry (ICP-MS): A pilot study. Anal. Lett. 2021, 54, 242-254. [CrossRef]

31. Schrauzer, G.N. Lithium: Occurrence, Dietary intakes, nutritional essentiality. J. Am. Coll. Nutr. 2002, 21, 14-21. [CrossRef]

32. González-Weller, D.; Rubio, C.; Gutiérrez Ángel, J.; González, G.L.; Mesa, J.M.C.; Gironés, C.R.; Ojeda, A.B.; Hardisson, A. Dietary intake of barium, bismuth, chromium, lithium, and strontium in a Spanish population (Canary Islands, Spain). Food Chem. Toxicol. Int. J. Publ. Br. Ind. Biol. Res. Assoc. 2013, 62, 856-868. [CrossRef]

33. García, J.C.R.; Rodríguez, R.I.; Crecente, R.M.P.; García, J.B.; Martín, S.G.; Latorre, C.H. Preliminary chemometric study on the use of honey as an environmental marker in Galicia (Northwestern Spain). J. Agric. Food Chem. 2006, 54, 7206-7212. [CrossRef] 